\title{
Coulisses
}

Revue de théâtre

2 | Automne 1990

Spécial Festival des idées : Besançon ville ouverte aux jeunes

\section{La Caverne des Contes. Le Trésor du Figuier par Rafik Harbaoui}

\section{Rédaction}

\section{OpenEdition}

\section{Journals}

Édition électronique

URL : http://journals.openedition.org/coulisses/1594

DOI : $10.4000 /$ coulisses. 1594

ISSN : 2546-9460

Éditeur

Presses universitaires de Franche-Comté

Édition imprimée

Date de publication : 1 novembre 1990

Pagination : $\mathrm{np}$

ISSN : 1150-594X

Référence électronique

Rédaction, «La Caverne des Contes. Le Trésor du Figuier par Rafik Harbaoui », Coulisses [En ligne], 2 I Automne 1990, mis en ligne le 04 juillet 2017, consulté le 21 octobre 2019. URL : http:// journals.openedition.org/coulisses/1594; DOI : 10.4000/coulisses.1594

Ce document a été généré automatiquement le 21 octobre 2019

Coulisses 


\section{La Caverne des Contes. Le Trésor du Figuier par Rafik Harbaoui}

\section{Rédaction}

1 Le conteur entre et s'assied sur le billot de bois. Constatant combien l'audience est réduite - une dizaine de personnes -, il nous invite à nous rapprocher.

2 Aussitôt commence un merveilleux voyage dans l'imaginaire, un imaginaire qui tient autant des Mille et une nuit que du Petit Prince de Saint-Exupéry. L'histoire est fondée sur la recherche d'un trésor, et rythmée par quelques phrases itératives. Mais rapidement, elle se ramifie, avec l'intervention de récits secondaires. Le conteur reste assis; il esquisse parfois quelques gestes. Il ne s'identifie jamais à ses personnages, quoiqu'il utilise le « je », pour indiquer que l'histoire est " celle de son enfance », mais face à soi, on a toujours le conteur adulte.

On se trouve tel un enfant à qui l'on raconte une histoire. Et lorsque le conteur demande au public de reprendre les phrases leit motiv, de l'aider à retrouver le fil de l'histoire, de proposer une solution à une devinette, les enfants participent spontanément, et les adultes se prennent très vite au jeu.

4 On découvre quel est "le trésor du figuier » lors d'un de ces échanges où diverses réponses convergent, chacune donnant naissance à un rameau d'où une histoire nouvelle pourrait éclore. Chacun apporte son avis sur la nature du trésor et, quoique la solution du conteur soit la plus acceptable, les diverses réponses s'amassent en conclusion et constituent un nouveau trésor, trésor de mots et de rêves déposés là par les auditeurs du conte. 


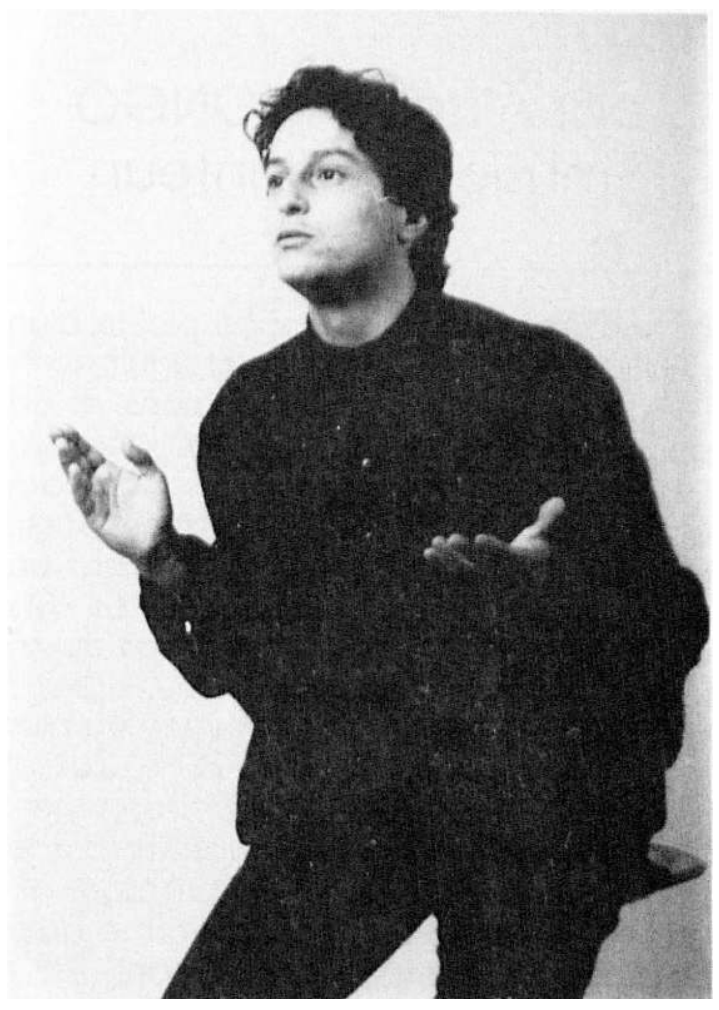

(c) Collectif Photo BVOJ 90. 